\title{
Expression of c-fms on Smooth Muscle Cells Isolated from Experimental Arteriosclerosis*
}

\author{
Toshimori Inaba ${ }^{1}$, Nobuhiro Yamada ${ }^{1, *}$, Takanari Gotoda ${ }^{1}$, \\ Yasushi Saito ${ }^{2}$, Sho Yoshida ${ }^{2}$, and Yoshio Yazaki ${ }^{1}$ \\ ${ }^{1}$ Third Department of Internal Medicine, University of Tokyo, Tokyo, Japan. \\ ${ }^{2}$ Second Department of Internal Medicine, University of Chiba, Chiba, Japan.
}

\begin{abstract}
In the present study, we demonstrated gene transcription of $c$-fms in smooth muscle cells isolated from an experimental rabbit model of arteriosclerosis (intimal smooth muscle cells), although there was no gene transcription of c-fms detected in medial smooth muscle cells. On immunocytochemical analysis, both types of smooth muscle cells similarly reacted with an antibody specific to muscle cells (HHF 35), but did not react with an antibody specific to rabbit macrophages (RAM 11). Intimal smooth muscle cells bound to acetylated LDL and resulting foam cell formation was observed. In response to M-CSF, an increased rate of cell proliferation was observed in intimal smooth muscle cells, but not in medial smooth muscle cells. These results indicated that intimal smooth muscle cells have monocytemacrophages characteristics such as the expression of $c$-fms and scavenger receptor gene.
\end{abstract}

Key words : Monocyte colony-stimulating factor, Atherosclerosis, c-fms

In early atherosclerosis, smooth muscle cells migrate from the media to the intima of the arterial wall, where they proliferate and endocytose various lipoproteins, rosulting in the formation of foam cells $(1,2)$. During the atherosclerotic process, smooth muscle cells undergo structural and functional changes (2). Although the precise mechanism of the phenotypic change is not fully understood, the involvement of various cytokines and growth factors was proposed in this phenotypic change of smooth muscle cells $(1,2)$.

In the arterial wall, various cytokines, such as interleukin-1, interleukin-6, tumor necrosis factor $\alpha$, interferons and colony stimulating factors, are reported to be synthesized and secreted by vascular cell components (36). Among the cytokines, M-CSF, an $85 \mathrm{kDa}$ homodimeric glycoprotein, specifically promotes growth and differentiation of the monocyte-macrophage lineage and activates various functions of mature macrophages (7-9). Recently, we demonstrated that M-CSF enhances scavenger receptor activity in human monocyte-derived macrophages, suggesting the possible involvement of M-CSF

This article was presented at the Winter 1991 meeting of the Japan Atherosclerosis Society in Tokyo.

* To whom all correspondence should be addressed. in the atherosclerotic process (10). The effects of M-CSF are mediated through binding to specific, high-affinity surface receptors encoded by the $c$-fms proto-oncogene (11). In the present study, two different phenotypes of smooth muscle cells were isolated: one from an experimental rabbit model of arteriosclerosis and another from normal arterial wall. Expression of $c$-fms was found in smooth muscle cells isolated from experimental arteriosclerosis.

\section{Experimental Procedures}

\section{Materials}

Sodium $\left[{ }^{125}\right]$ iodide and $\left[{ }^{3} \mathrm{H}\right]$-thymidine were purchased from ICN Radiochemicals. ${ }^{125}$ I-PDGF-BB homodimer was purchased from Amersham. Recombinant human M-CSF was a purified product obtained from Morinaga Milk Industry Co., Ltd. (Tokyo, Japan). PDGF-BB homodimer was purchased from Genzyme. All other chemicals were of analytical grade.

\section{Cells}

Intimal smooth muscle cells were isolated and cultured as described previously (12). Medial smooth muscle cells 
were explanted from an intact rabbit aorta using the method described by Fischer-Dzoga et al. (13). Both cell cultures were passaged 4 times by trypsinization and seeded in $2 \mathrm{ml}$ of DME containing 10\% fetal bovine serum (FBS) in 35-mm dishes. Indirect immunofluorescence on rabbit smooth muscle cells was performed on multiwelled slides fixed in $-20^{\circ} \mathrm{C}$ methanol for $5 \mathrm{~min}$ as described previously (14). A monoclonal anti-muscle cell antibody HHF35, was generated using human myocardium as the immunogen. Monoclonal anti-macrophage antibody RAM11 was produced against rabbit alveolar macrophages and did not react with cultured rabbit aortic smooth muscle cells (14).

\section{Northern blot hybridization analysis and quantitative anal-} ysis of M-CSF receptor mRNAs

Total RNA of smooth muscle cells was isolated by the guanidine hydrochloride method. Twenty $\mu \mathrm{g}$ of total RNA was electrophoretically fractionated on $1 \%(w / v)$ agarose/2.2 M formaldehyde gel and transferred onto a nylon membrane in $20 \times \operatorname{SSPE}\left(3.6 \mathrm{M} \mathrm{NaCl}, 0.2 \mathrm{M} \mathrm{Na}_{2}\right.$ $\mathrm{HPO}_{4}$ and $2 \mathrm{mM}$ EDTA, pH 7.7). The membrane was hybridized as described previously (15) with the CDNA probe coding for $v$-fms (16). The competitive PCR method was used to accurately measure mRNA levels (17). One $\mu \mathrm{g}$ of total RNA from the respective cell types was reverse-transcribed for $60 \mathrm{~min}$ at $37^{\circ} \mathrm{C}$ in a reaction mixture $(25 \mu \mathrm{l})$ containing $50 \mathrm{mM}$ Tris $(\mathrm{pH} \mathrm{8.3),} 75 \mathrm{mM} \mathrm{KCl}$, $3 \mathrm{mM} \mathrm{MgCl}_{2}, 10 \mathrm{mM}$ dithiothreitol, $5 \mathrm{nmol}$ of each deoxynucleoside triphosphate (dNTP), 5 units of ribonuclease inhibitor from human placenta (Takara, Tokyo) and 200 units of Moloney murine leukemia virus reverse transcriptase (Bethesda Research Laboratories) with 100 pmol of random hexamer primers (Pharmacia). The DNA fragment of rabbit c-fms gene $(200 \mathrm{bp})$ was preparatively amplified with a pair of primers (primer $A ; 5^{\prime}-$ CGTAACGTGCTGTTGACCAA and primer $\mathrm{B} ; 5^{\prime}-$ CTCTGAACCGTGTAGACACA) and used in competitive PCR as a control template. Aliquots of the cDNA products were co-amplified with indicated amounts of the control DNA (220 bp) using the same set of primers (primer $A$ and $B)$.

\section{Binding assays}

The specific bindings of ${ }^{125}$ I-M-CSF, ${ }^{125}$ I-PDGF-BB homodimer and ${ }^{125}$-acetylated LDL were studied in intimal and medial smooth muscle cells. M-CSF was iodinated without loss of biological activity using the method described by Stanley(18). Smooth muscle cells were grown in DME medium supplemented with $10 \%$ FBS and used for experiments at the 4th to 6 th passages. Smooth muscle cell monolayers were incubated at $2^{\circ} \mathrm{C}$ for $3 \mathrm{~h}$ with medium containing the indicated amounts of ${ }^{125}$-labeled M-CSF or ${ }^{125}$-labeled PDGF and $2 \mathrm{mg} / \mathrm{ml}$ bovine serum albumin, washed twice with phosphate-buffered saline and solubilized with a buffer containing $10 \%(v / v)$ glycerol,
$1 \%(v / v)$ Triton $\mathrm{X}-100$, and $20 \mathrm{mM}$ HEPES, $\mathrm{pH} 6.8$, at room temperature for $2 \mathrm{~h}$. Nonspecific binding was determined by the addtion of a 40 -fold excess of unlabeled M-CSF or PDGF-BB homodimer (Genzyme). Binding assay of ${ }^{125}$ /-acetylated LDL was performed as described previously (10). Nonspecific binding was subtracted from total binding.

\section{Effects of M-CSF and PDGF on cell growth in intimal and} medial smooth muscle cells

In the experiment to determine the cellular uptake of $\left[{ }^{3} \mathrm{H}\right]$-thymidine, smooth muscle cells were seeded at a density of $10^{5}$ cells $/ \mathrm{ml}$ and cultured for $24 \mathrm{~h}$ prior to the experiment. After incubating with the indicated amount of M-CSF or PDGF-BB homodimer for $72 \mathrm{~h}, 5 \mu \mathrm{Ci} / \mathrm{ml}$ of $\left[{ }^{3} \mathrm{H}\right]$-thymidine $(1 \mathrm{mCi} / \mathrm{ml} ; \mathrm{ICN})$ was added, and incubated for an additional $4 \mathrm{~h}$. The radioactivity in the cells was then determined. $100 \%$ indicates uptake of $\left[{ }^{3} \mathrm{H}\right]$ thymidine in the absence of M-CSF or PDGF.

\section{Light microscopic examination of smooth muscle cells}

Cells were cultured on multiwelled slides as described. For light microscopic examination, the cells were cultured with $100 \mu \mathrm{g} / \mathrm{ml}$ of acetylated LDL at $37^{\circ} \mathrm{C}$ for 3 days. Then, the cells were fixed with $6 \%$ paraformaldehyde in $0.1 \mathrm{M}$ sodium phosphate, $\mathrm{pH} 7.3$, and stained with Oil Red $\mathrm{O}$ and hematoxylin.

\section{Results}

\section{Immunocytochemical analysis}

We performed immunocytochemical studies to characterize two different types of smooth muscle cells ; intimal smooth muscle cells were isolated from thickened intima of cannulated aorta and medial smooth muscle cells were isolated from normal intact artery using monoclonal antibodies specific for muscle cells and macrophages. As shown in Fig. 1, intimal smooth muscle cells reacted with antibody specific to muscle cells (HHF 35), but failed to react with antibody specific to rabbit macrophages (RAM 11)(14). This indicated that the intimal smooth muscle cells that we isolated were immunologically different from macrophages, and similar to medial smooth muscle cells.

\section{M-CSF receptor mRNA}

In smooth muscle cells M-CSF receptor encoded by $c$-fms was detected using the cDNA probe for $v$-fms (16). Northern blot hybridization analysis of RNA obtained from intimal smooth muscle cells demonstrated appreciable amounts of M-CSF receptor mRNA with a length of $4.5 \mathrm{~kb}$, whereas there was no mRNA detected in normal medial smooth muscle cells. To determine M-CSF receptor mRNA levels in either intimal smooth muscle cells or medial smooth muscle cells, we utilized the competitive polymerase chain reaction (PCR) method. As shown in Fig. 2, the amplified fragments for cDNA (159 bp) were 

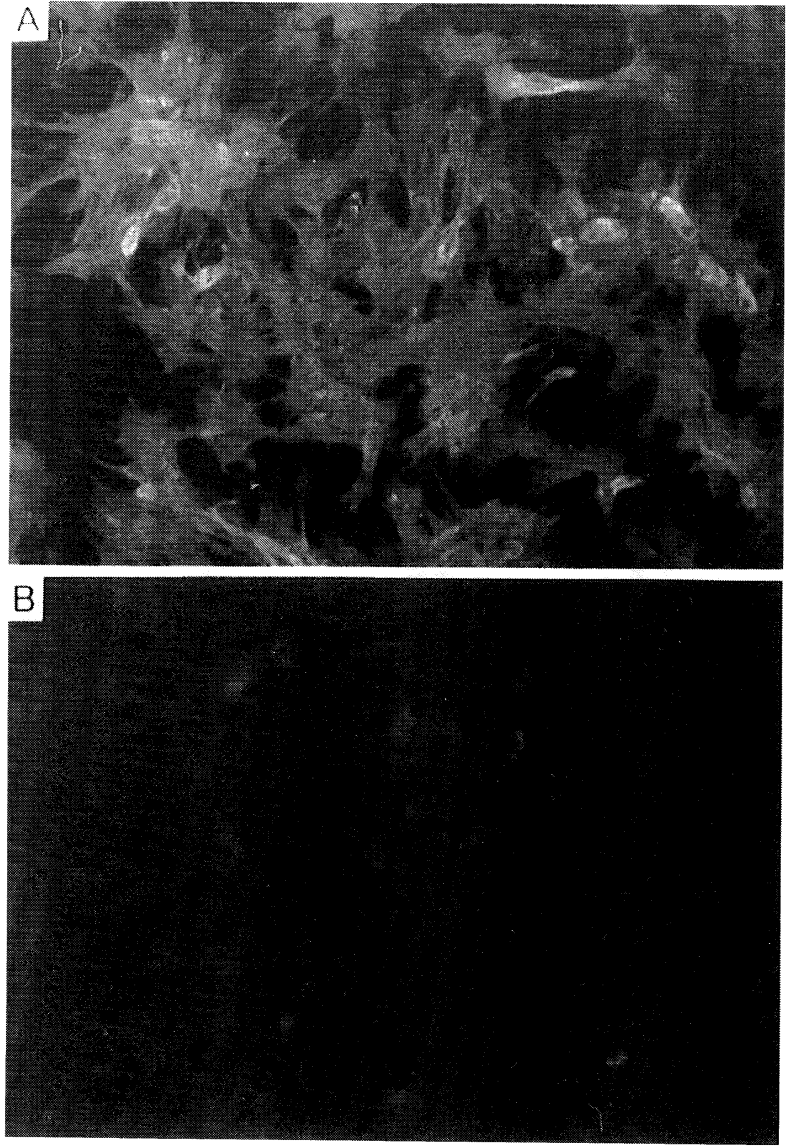

Fig. 1. Immunocytochemical analysis of rabbit smooth muscle cells. Indirect immunofluorescence of smooth muscle cells was performed on multiwelled slides. Intimal smooth muscle cells reacted with anti-muscle cell antibody HHF35 (A) and anti-macrophage antibody RAM11 (B). Ascites fluids of RAM11 and HHF 35 were diluted with phosphate-bufferred saline to $1: 1,000$ and $1: 500$, respectively. shorter than those for genomic DNA (220 bp) due to lack of intron. The same amount of $220 \mathrm{bp}$ and $159 \mathrm{bp}-$ fragments was obtained when the amounts of $220 \mathrm{bp}$ fragment were $1 \times 10^{-1}$ and $1 \times 10^{-5} \mathrm{pg} / \mu \mathrm{l}$ for cDNAs obtained from intimal and medial smooth muscle cells, respectively. Thus, the amount of M-CSF receptor mRNA transcribed in intimal smooth muscle cells was approximately 10,000 -fold the amount transcribed in medial smooth muscle cells.

\section{Binding assays of M-CSF and PDGF}

Binding assay with iodinated M-CSF on intimal smooth muscle cells at $2^{\circ} \mathrm{C}$ demonstrated high affinity binding of M-CSF with saturation kinetics. Scatchard analysis of the binding data of ${ }^{125} \mathrm{I}-\mathrm{M}-\mathrm{CSF}$ revealed a single class of binding sites (Bmax; $40.6 \mathrm{f} \mathrm{mol} / \mathrm{mg}$ cell protein) with an apparent binding affinity $(\mathrm{Kd})$ of $24 \mathrm{pM}$ calculated by

\section{medial SMC}

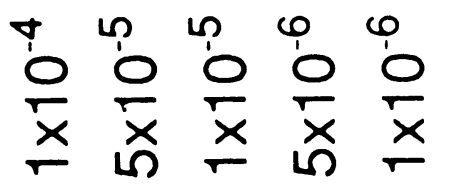

$(p g / \mu l)$

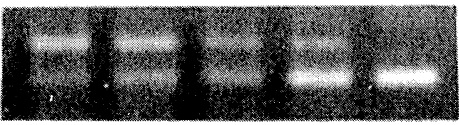

$220 \mathrm{bp}$

$159 \mathrm{bp}$

\section{intimal SMC}

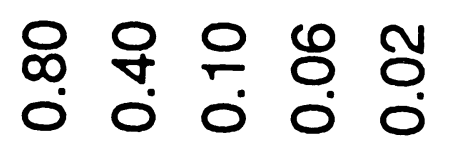

$(\mathrm{pg} / \mu \mathrm{l})$
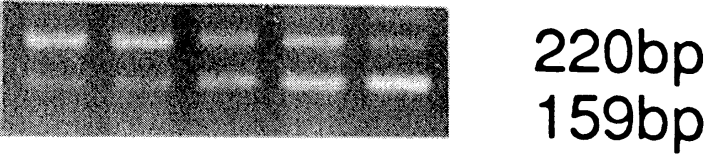

Fig. 2. Quantitative analysis of $M-C S F$ receptor mRNAs isolated from intimal smooth muscle cells and medial smooth muscle cells. One $\mu \mathrm{g}$ of total RNAs from the respective cell types were reverse-transcribed with random hexamer primers. The DNA fragment of rabbit $c$-fms gene $(220 \mathrm{bp})$ was preparatively amplified with a pair of primers and used in the competitive PCR an a control template. Aliquots of the cDNA products were co-amplified with indicated amounts of the control DNA (220bp).

linear regression. No M-CSF binding was demonstrated on medial smooth muscle cells (Fig. 3). We also found that iodinated PDGF (BB) bound to both intimal and medial smooth muscle cells; Bmax in binding of iodinated PDGF (BB) to intimal smooth muscle cells $(631 \mathrm{fmol} / \mathrm{mg}$ cell protein) was 1.23-fold greater than that to medial smooth muscle cells $(512 \mathrm{fmol} / \mathrm{mg}$ cell protein). Binding affinities were not different between the two cell types; 535 $\mathrm{pM}$ for medial smooth muscle cells and $464 \mathrm{pM}$ for intimal smooth muscle cells. These results indicated that intimal smooth muscle cells have both M-CSF receptor and PDGF receptor on the cell surface, whereas normal medial smooth muscle cells lack M-CSF receptor.

We studied the effects of M-CSF on the growth of either intimal or medial smooth muscle cells. $\left[{ }^{3} \mathrm{H}\right]$-thymidine uptake and the cell growth curve (data not shown) indicated that enhanced proliferation in response to M-CSF 

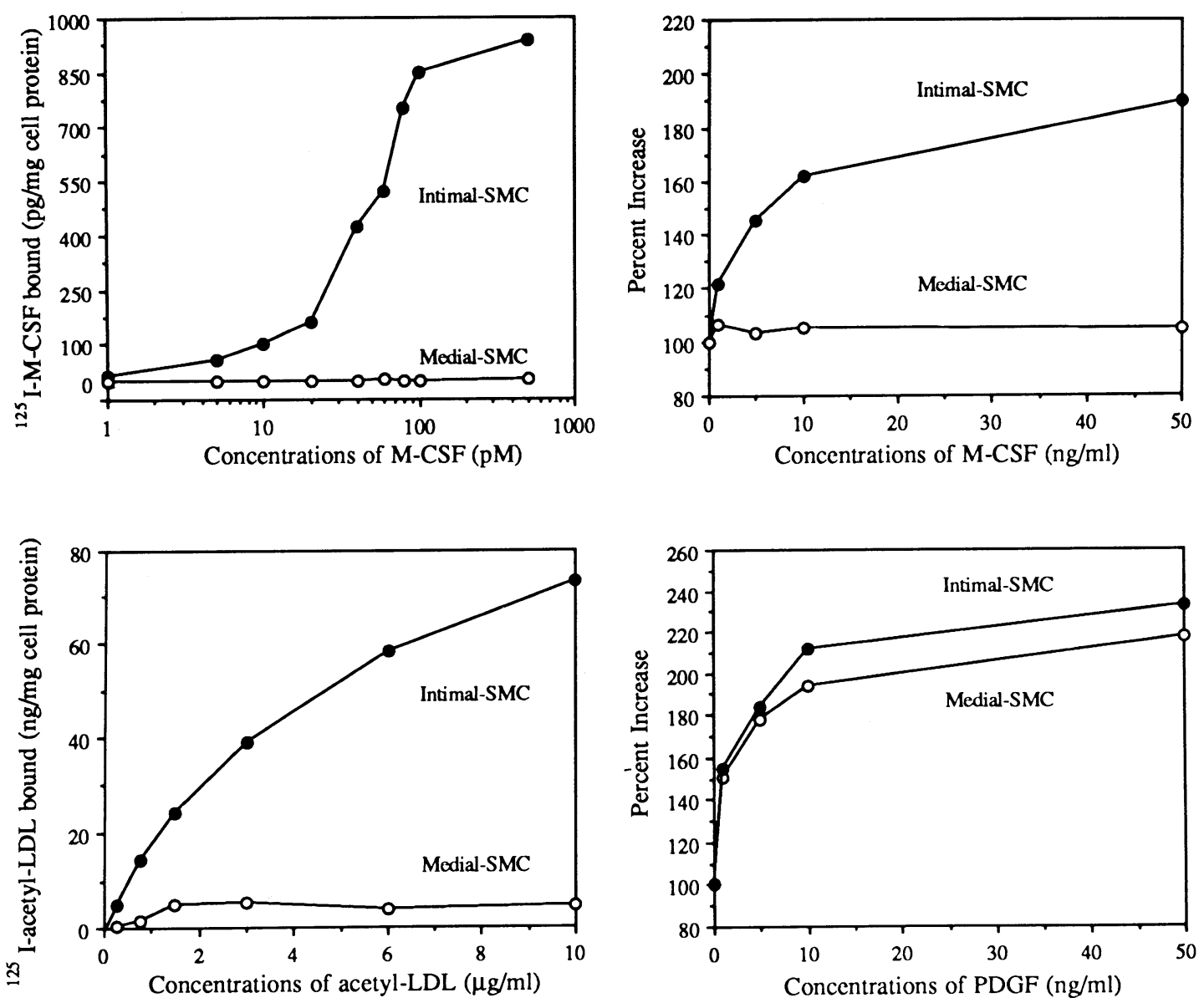

Fig. 3. a-Specific binding of ${ }^{125}$-M-CSF in intimal and medial smooth muscle cells (left upper). Smooth muscle cells were grown in DEM medium supplemented with $10 \%$ FBS and used for experiments at the 5th passage. Smooth muscle cell monolayers were incubated at $2^{\circ} \mathrm{C}$ for $3 \mathrm{~h}$ with medium containing the indicated amounts of ${ }^{125}$-labeled M-CSF. Each value represents the mean of triplicate wells. b-Effects of M-CSF and PDGF on cell growth in intimal and medial smooth muscle cells (right). After incubating with the indicated amount of M-CSF (right upper) or PDGF-BB homodimer (right lower) for $72 \mathrm{~h},\left[{ }^{3} \mathrm{H}\right]$-thymidine was added, and incubated for an additional $4 \mathrm{~h}$. The radioactivity in the cells was then determined. $100 \%$ indicates uptake of $\left[{ }^{3} \mathrm{H}\right]$-thymidine in the absence of M-CSF or PDGF. Each value represents the mean of triplicate wells. C-Specific binding of ${ }^{125} /$-acetylated LDL in intimal and medial smooth muscle cells (left lower). After preincubating in medium containing $5 \mathrm{mg} / \mathrm{ml}$ of lipoprotein deficient serum (LPDS) with or without M-CSF for $24 \mathrm{~h}$, smooth muscle cells were incubated with $1 \mathrm{ml}$ of medium containing $5 \mathrm{mg} / \mathrm{ml}$ of LPDS and varying concentrations of ${ }^{125} \mathrm{l}$-acetyl-LDL at $4^{\circ}$ $\mathrm{C}$ for $2 \mathrm{~h}$. Then the amounts of ${ }^{125}$ l-labeled lipoproteins associated with cells were determined. Each value represents the mean of triplicate wells.

occurred only in intimal smooth muscle cells and not in medial smooth muscle cells, whereas enhanced proliferation in response to PDGF was observed in both cell types.

\section{Scavenger receptor activity}

As shown in Fig. 3, acetylated LDL was taken up by intimal smooth muscle cells with saturation kinetics $(\mathrm{Kd}=$ $6.2 \mu \mathrm{g} / \mathrm{ml}$ ), and we found that $10 \mathrm{ng} / \mathrm{ml}$ of M-CSF increased the Bmax 1.7-fold from 64.6 to $108.9 \mathrm{ng} / \mathrm{mg}$ cell protein, whereas there was no uptake of acetylated LDL in medial smooth muscle cells. The receptor proteins were visualized by incubating a nitrocellulose strip with ${ }^{125}$ Iacetyl-LDL (data not shown). Ligand blots revealed that ${ }^{125}$ l-acetyl-LDL bound to a protein of $240 \mathrm{kD}$ specifically in both intimal smooth muscle cells grown with M-CSF and those grown without it. The intensity of the band was increased by M-CSF treatment. Addition of excess unlabeled acetyl-LDL almost completely displaced this band of $240 \mathrm{kD}$. Therefore, this band might represent receptor protein for acetyl-LDL. Furthermore, accumulation of 

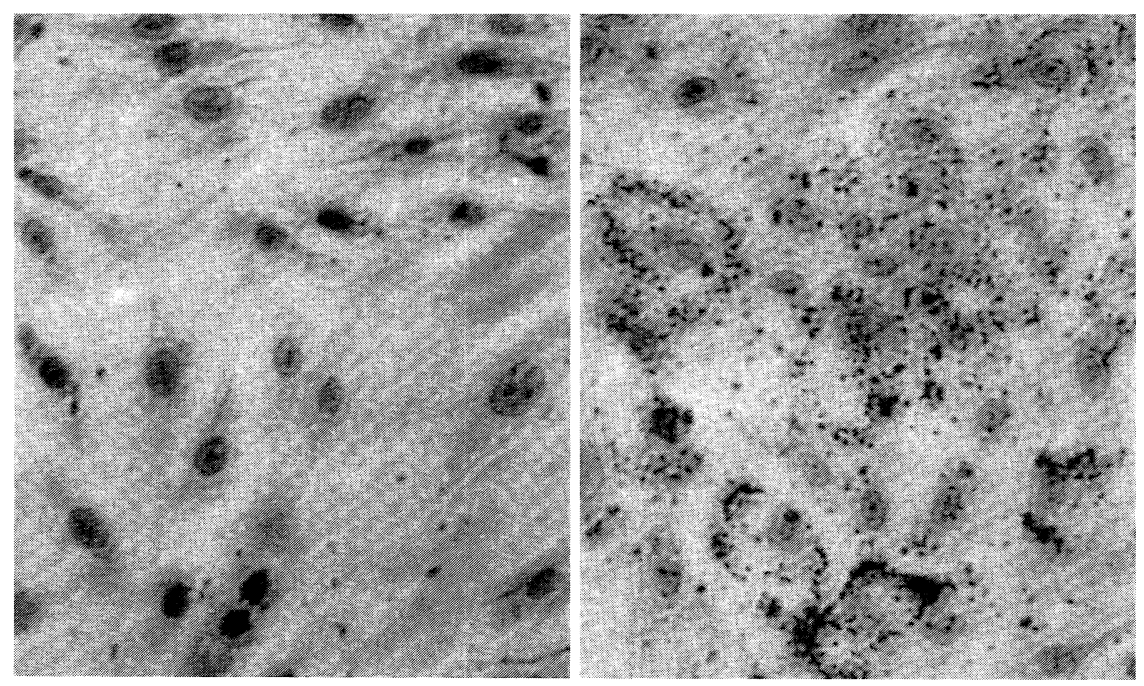

Fig. 4. Light microscopic examinations of smooth muscle cells. Cells were cultured on multiwelled slides. The cells were cultured with $100 \mu \mathrm{g} / \mathrm{ml}$ of acetylated LDL at $37^{\circ} \mathrm{C}$ for 3 days. Then, the cells were stained with Oil Red $\mathrm{O}$ and hematoxylin (left, medial smooth muscle cells; right, intimal smooth muscle cells).

acetylated LDL in intimal smooth muscle cells was visualized by light microscopic examination after incubation with acetylated LDL at $37^{\circ} \mathrm{C}$ (Fig. 4). In medial smooth muscle cells incubated with acetylated LDL, only occasional small lipid droplets were observed after staining with Oil Red O. In contrast, intimal smooth muscle cells incubated with the same amounts of acetylated LDL (100 $\mu \mathrm{g} / \mathrm{ml}$ ) showed remarkable staining with Oil Red $\mathrm{O}$, and lipid droplets were observed in every cell which indicated that medial smooth muscle cells did not grow in the culture of intimal smooth muscle cells.

\section{Discussion}

The action of M-CSF was mediated through binding to specific, high-affinity surface receptors encoded by the c-fms proto-oncogene (11), and the expression of M-CSF receptor on cells generally coincided with their differentiation to the monocyte-macrophage lineage. M-CSF receptors have not been demonstrated in normal vascular smooth muscle cells. In the present study, the expression of c-fms was demonstrated in smooth muscle cells isolated from an experimental arteriosclerosis (intimal smooth muscle cells) with an mRNA level of 10,000-fold that of medial smooth muscle cells. The immunocytochemical study showed that intimal smooth muscle cells were immunologically different from macrophages, but similar to normal medial smooth muscle cells as shown in Fig. 1.

It is well known that macrophages endocytose acetylated LDL through a scavenger receptor in vitro (19). As shown in Figs. 3 and 4, the intimal smooth muscle cells acquired this characteristic function of macrophages, as acetylated LDL bound to intimal smooth muscle cells. Pitas et al. (20) and Jaakkola et al. (21) reported the expression of scavenger receptor activity in smooth muscle cells isolated from atherosclerotic rabbit aorta, although most smooth muscle cells did not express this activity. In the current study, we demonstrated the expression of both $\mathrm{c}$-fms and scavenger receptor in smooth muscle cells isolated from arteriosclerotic lesions. These findings suggest that the mechanism underlying the process of atherosclerosis or injury to the arterial wall induced alterations in the regulation of normal $c$-fms gene expression in smooth muscle cells, and induced phenotype conversion to foam cells. The expression of the c-fms gene in smooth muscle cells may initiate biological events such as growth and differentiation to monocyte-macrophage-like cells, and scavenger function through interaction with M-CSF.

Furthermore, we demonstrated that both M-CSF and PDGF bind to intimal smooth muscle cells, and induce cell growth. It was proposed that PDGF regulates the proliferation and migration of vascular smooth muscle cells via specific receptors $(1,2)$. PDGF receptors and M-CSF receptors are generally expressed in a mutually exclusive manner, i.e., the PDGF receptor is expressed on mesenchymal cells and the M-CSF receptor is expressed primarily on monocyte-macrophages. Roberts et al. (22) reported the tandem linkage of these genes and suggested that the close approximation of the two genes may suppress $c$-fms transcription in mesenchymal cells. Taking into account the $c$-fms and scavenger receptor expression in intimal smooth muscle cells, our these 
results indicated that smooth muscle cells isolated from arteriosclerotic lesions have distinct characteristics such as the coexpression of PDGF receptor, M-CSF receptor and scavenger receptor on the cell surface. Therefore, the intimal smooth muscle cells isolated from rabbit arteriosclerotic lesions acquired characteristics of both macrophages and smooth muscle cells. The present results indicate that the expression of the c-fms gene in smooth muscle cells coincides with the phenotypic conversion of smooth muscle cells to the phagocytic phenotype found in atherosclerotic lesions, and that this c-fms gene expression may play an important role in the proliferation and differentiation of vascular smooth muscle cells.

Finally, we administered human recombinant M-CSF to Watanabe heritable hyperlipidemic (WHHL) rabbits, an animal model for familial hypercholesterolemia to elucidate the effects of M-CSF in the atherogenic process in vivo. Three hundred $\mu \mathrm{g}$ of M-CSF was intravenously injected into WHHL rabbits aged 2.5 months, three times a week for 8.5 months. After M-CSF treatment, the progression of atherosclerosis was very retarded. The accumulation of cholesterol ester was remarkably decreased in the aortae of M-CSF-treated animals $(0.60 \pm$ $0.32 \mathrm{mg} / \mathrm{g}$ tissue), compared to those of controls (4.32 \pm $0.61 \mathrm{mg} / \mathrm{g}$ tissue). Furthermore, the percentage of the surface area of the aorta with macroscopic plaque in animals treated with $\mathrm{M}-\mathrm{CSF}$ was $14.3 \pm 6.2 \%$, much less than that in controls receiving saline injection $(38.8 \pm$ $8.0 \%$ ). Thus, M-CSF definitely prevented the progression of atherosclerosis in WHHL rabbits by influencing cellular functions through the interaction with M-CSF receptors in the vascular wall.

\section{References}

(1) Ross R, Raines EW, and Bowen-Pope DF : The biology of platelet-derived growth factor. Cell, 46:155-169, 1986

(2) Thyberg J, Hedin U, Sjolund M, Palmberg L, and Bottger B: Regulation of differentiated properties and proliferation of arterial smooth muscle cells. Arteriosclerosis, 10: 966-990, 1990

(3) Warren MK and Ralph RJ: Macrophage growth factor CSF-1 stimulates human monocyte production of interferon, tumor necrosis factor, and colony-stimulating activity. J Immunol, 137 : 2281-2285, 1986

(4) Navarro S, Debili N, Bernaubin J, Vainchenkev J, and Doly $\mathrm{J}$ : Regulation of the expression of IL-6 in human manocytes. J Immunol, 142: 4339-4345, 1989

(5) Motoyoshi K, Yoshida K, Hatake K, Saito M, Miura Y, Yanai N, Yamada M, Kawashima T, Wong GG, Temple PA, Leary AC, Witek-Giannoti JS, Fujisawa M, Yuo A, Okabe $T$, and Takaku $F$ : Recombinant and native human urinary colony-stimulating factor directly augments granurocytic and granurocyte-macrophage colony-stimulating factor production of human peripheral blood manocytes. Exp Hematol, 17 : 68-71, 1989
(6) Hansson GK, Jonasson L, Seifert PS, and Stemme S: Immune mechanisms in atherosclerosis. Arteriosclerosis, 9: 567-578, 1989

(7) Clark SC and Kamen R: The human hematopoietic colony-stimulating factors. Science, 236: 1229-1237, 1987

(8) Wong GG, Temple AA, Leary AC, Witek-Giannoti JS, Yang YC, Ciarletta AB, Chung $C$, Murtha P, Kritz R, Kaufman RJ, Ferenz CR, Sibley BC, Turner KJ, Hewick RM, Clark SC, Yanai N, Yokota H, Yamada M, Saito M, Motoyoshi K, and Takaku F: Molecular cloning and expression of 4-kb cDNA encoding the human urinary protein. Science, 235: 1504-1508, 1987

(9) Shimano H, Yamada N, Ishibashi S, Harada K, Matsumoto A, Mori N, Inaba T, Motoyoshi K, Itakura $\mathrm{H}$, and Takaku F: Human monocyte colony-stimulating factor enhances the clearance of lipoproteins containing apo B-100 via both LDL receptor-dependent and -independent pathways in rabbits. J Biol Chem, 265 : 1286912875, 1990

(10) Ishibashi S, Inaba T, Shimano H, Harada K, Inoue I, Mokuno H, Mori N, Gotoda T, Takaku F, and Yamada N: Monocyte colony-stimulating factor enhances uptake and degradation of acetylated low density lipoproteins and cholesterol esterification in human monocytederived macrophages. J Biol Chem, 265 : 14109-14117, 1990

(11) Sherr CJ, Rettenmier CW, Sacca R, Roussel MF, Look AT, and Stanley ER: The $c$-fms proto-oncogene product is related to the receptor for the mononuclear phagocyte growth factor, CSF-1. Cell, 41: 665-676, 1988

(12) Saito Y, Bujo H, Morisaki N, Shirai K, and Yoshida S : Proliferation and LDL binding of cultured intimal smooth muscle cells from rabbits. Atherosclerosis, 69 : 161-164, 1988

(13) Fisher-Dzoga K, Jones RM, Vesselinovitch D, and Wissler RW: Ultrastructural and immunohistochemical studies of primary cultures of aortic medial cells. Exp Mol Pathol, 18: 162-176, 1973

(14) Tsukada T, Rosenfeld M, Ross R, and Gown AM: Immunocytochemical analysis of cellular components in atherosclerotic lesions. Use of monoclonal antibodies with the Watanabe and fat-fed rabbit. Arteriosclerosis, 6: 601-613, 1986

(15) Gotoda T, Senda M, Murase T, Yamada N, Takaku F, and Furuichi $Y$ : Gene polymorphism identified by Pvull in familial lipoprotein lipase deficiency. Biochem Biophys Res Commun, 164 : 1391-1396, 1989

(16) Hampe A, Gobet M, Sherr CJ, and Galibert F : Nucleotide sequence of the feline retroviral oncogene $v$-fms shows unexpected homology with oncogenes encoding tyrosine-specific protein kinases. Proc Natl Acad Sci USA, 81: 85-89, 1984

(17) Gilliland G, Perrin S, Blanchard K, and Bunn HF : Analysis of cytokine mRNA and DNA : detection and quantitation by competitive polymerase chain reaction. Proc Natl Acad Sci USA, 87 : 2725-2729, 1990

(18) Stanley ER: The macrophage colony-stimulating factor, CSF-1. Methods Enzymol, 116 : 564-587, 1985

(19) Kodama T, Frreman M, Rohrer L, Zabrecky J, Matsudaira $P$, and Krieger $M$ : Type I macrophage scavenger receptor contains $\alpha$-helical and collagen-like coiled coils. Nature, 343: 531-535, 1990 
(20) Pitas RE, Innerarity TL, and Mahley RW : Foam cells in explants of atherosclerotic rabbit aortas have receptors for $\beta$-very low density lipoproteins and modified low density lipoproteins. Arteriosclerosis, 3: 2-12, 1983

(21) Jaakkola $O$, Kallioniemi $O$, and Nikkari I: Lipoprotein uptake in primary cell cultures of rabbit atherosclerotic lesions: A fluorescence microscopic and flow cytometoric study. Atherosclerosis, 69: 257-268, 1988

(22) Roberts WM, Look AT, Roussel MF, and Sherr CJ: Tandem linkage of human CSF-1 receptor (c-fms) and PDGF receptor genes. Cell, 55 : 665-671, 1988 